\title{
Contextualizing Cultural Identity for Integration and Manipur Experience
}

\author{
Dr. Ngamkhohao Haokip, PhD, (UGC DSRPDFHS Research Fellow)
}

\begin{abstract}
Some common terms which are in vogue in the definitions of 'culture' or 'cultural identities' are contextualized with the experiences of different communities of Manipur. The paper then discusses various historical and contemporary social, political, and religious experiences of the people and how these experiences affected contemporary societies in Manipur. The different cultural identities practiced by hill tribes and the plain caste which could be integrated to achieve both political and economic ends through embodiment of the experiences are also discussed. In the process of the discussion, the political system of the State that underplays common cultural formation is unavoidable, in the perspective of the paper, and is thus discussed.
\end{abstract}

Keywords: Commanding community, cultural, experience, tribal, politics, identities

\section{Introduction}

The Prime Minister of India Narendra Damordardas Modi belongs to "Ghanchi caste, traditionally producers of vegetable oil" and "OBC" (Marino, 2014, p. 5), and Andy Marino, the writer of his 'Political Biography', wonders "how significant this social ranking and disadvantage would have felt to young Narendra in a small, rural town [...]" and how a kind of advice like "[d]on't focus on the deficiencies. Each and every person has so many deficiencies, but you have to focus on his (positive) qualities" has influenced Modi (Marino, 2014, p. 17). It is interesting to note what Marino has to say more about cultural environment of Modi's upbringing and I quote him "[w]ould Modi be challenging for the prime ministership had he not been suffused [covered throughout] by the same environment that created Mahatma Gandhi, Sardar Vallabhbhai Patel and yes - Muhammad Ali Jinnah? It is unlikely his appeal, had it developed elsewhere, [if not in the cultural life in Gujarat] would have crossed many state boarders. Everybody is shaped and limited by their environment" (Marino, 2014, p. 13). So, Modi's 'culture or cultural identity' today is not what he defines it is without giving due consideration of those cultural, social and political situation that befallen him, which I term 'defining environment'. His /her environment thus, defines one's culture. However, one thing is very clear that the 'culture' simply describes his environment but that culture does not define him or what he is today or what he would ultimately become in future.

I introduced to you Mr. Narendra Modi in a nutshell. What he was and what he is, as prime minister of India, is worth emulating. Gujarat shaped and moulded Modi. The cultural settings foster by different communities in Manipur are unique in relation to one another. In spite of deficiencies each community in Manipur has, people there are, after all, shaped and moulded in Manipur and her history has leaded them thus far. And to embody all of the cultures is to contextualize them on the people as a whole base on their shared historical, geographical, socio-religious, and, of course, their political experiences in the past as well as at present.

\section{Contextualizing Cultural Identities and Integration}

Now, without having to exhaustively deal with each and every definitions of 'culture' as defined or propounded by anthropologists, theoreticians, and others, due to economy of space here, let us pick up some common terms used by some of them to suit the approach advance here. While defining 'culture', Edward Bernett Tylor emphasises on culture as something "acquired" (Jha, 1999, p. 21); David Bidney talks about "socio-facts" as an important element of 'culture' (Jha, 1999, p. 22); and Margaret Mead lays emphasis on "personality structure" in defining culture (Jha, 1999, p. 23). Here, we have three important vocabularies namely, 'acquired', 'socio-facts', and, of course, 'personality structure' to contextualize with the experiences in Manipur.

In Indian social dynamism also, 'Sanskritization' is about, apart from other things, "change”, change to a new form of socio-cultural life from traditional realm and to 'uplift the down trodden sections of society' in proximity with the 'socio-facts' proposition of culture which in turn is corollary with the concept of caste politics, the purpose of which is "to transfer authority from the higher to the lower and middle caste" groups. The process here will be nothing but 'acquiring' new culture through change of social system. Indian modernization during the British period was not without loopholes. Jha opines that " $[\mathrm{t}]$ he growth of this process was selective and segmented. It was not integrated with the microstructures of the Indian society, such as 
family, caste and village community. At these levels, the British by and large followed a policy of least interference, [....] (Jha, 1999, p. 203) in which the 'acquired' as well as the 'personality structure' of culture are gained. This is because the modernization brought in by the British system into the socio-cultural life of the Indian people did not affect all sections of the Indian societies. The modernization was mainly concentrated with the elite higher caste and urban population and the lower castes, villagers and small communities in rural India were not affected.

There are many opinions such as one given by Parekh (2009) that "[t]he only way to regenerate India was to make a clean break with the past by giving it a wholly new and modern identity" (Parekh, 2009, p. 118). Here the emphasis is on acquiring new culture. This line of thought also holds in the case of Manipur. This is because the process of modernization and change that took place in India as a whole and in Manipur particularly were 'controlled', 'manipulated', and 'hijacked' by the British policy of 'divide and rule'. What is encouraging is inasmuch as India got independence, under which she 'decides her own destiny'. There is nothing more powerful and authoritative than the avenue that gives political State the full-strength authority to decide its future course of actions. Similar is the case with Manipur. No opportunity other than one they have will offer better chance to draw their own future, future of cultural change. This is more so because of the fact that nothing is more accommodative and inclusive than democracy.

In developing countries, the debate on national identity continues. Their problem is that while "[t]hey want to modernize themselves, but they want to retain much of their traditional way of life. As the two are not easy to reconcile, their deeply divided self-consciousness periodically triggers off intense debates about who they were and have become, where they are going and what kind of society they are creating" (Parekh, 2009, pp. 118-9). This is true to India and her peripheral federating States like Manipur. There are four irreconcilable cultures in Manipur as of now. The division between the hill tribals and the valley castes is too wide a gap that bridging them will be possible only through inclusive politics and mutual understanding of one another's cultures in order to embody them into a single-whole system. This, to one's dismay, is yet to take place because of lackadaisical attitude of the political power of the Sate which has viable ambiance of duty, if so desire, to unite them. It must be remembered here that every issues in the State is 'politicized' thereby making things more political than otherwise and therefore necessitating to take a 'political approach' to blending cultural differences in the State. Nevertheless, in 'political approach' here, people will be totally opposed to exclusive, partial, and imposing State policies and plans which are alleged to have been happening.

Another challenge on the question of cultural identity and fight for political space based on cultural difference in the west that can be contextualized with the experiences of Manipur is the case of Scotland. A debate on 'battle for Scotland' is going on in England where, as reported by the The Hindu, the "opinion held thus far on the issue, the 'no' [to independence of Scotland from United Kingdom] sentiment has prevailed [...]". It is further reported that "the issues debated ranged from economy to nuclear weapons" and that "Mr. Darling [Alistair Darling, 'former Britain Prime Minister Tony Blair's media manager] emphasised the "best of both worlds' argument for staying together [....]" and said that "[t]he social justice obligations and economic growth policies could be addressed by a more empowered Scottish Parliament", and "added" that 'No thanks' [to independence] is not 'no change"' (Menon, 2014). In Manipur, bargaining for 'Alternative Arrangement' of the Nagas and 'Kuki Homeland' or political 'Kuki State' under the constitution of India of the Kukis based on cultural differences and alleged political and economic subjugations in the hands of the majority communities is a case in point. Even if the prevailing situations is the making of the elite groups in the State or some other actors, whether Balkanizing the State into three political entities and things like that or no Balkanizing to allow change to take place is for the people to decide, especially by the commanding community. Should this option in either way fail by adopting any other drastic actions to contain them will not be either a good one for all as the seeds of distrust created by Sate policies has rooted in the people.

\section{Manipur Experience}

In conjunction with the terms borrowed, as cited above, let us look into what the 'acquired' cultures have been, in Manipur. Two waves of 'cultural renaissance' took place long after cultural identities have been formed and consolidated. The 'Vaishnavite Hinduism' was 'selective' and 'segmentary' as it reformed only majority of the plain dwellers. We could not trace any record of any attempt being made to convert or reform the hill dwellers into Hinduism. The second wave, of course, was the proselytization of the hill dwellers into Christianity. In this case, the attempt made to convert the Hinduized Meeteis by Christian missionaries is a known fact. Although these epochs in the history have compartmentalized their culture, at least religiously, local Christian missionaries are working in this line in order to break the' Berlin Wall', whereas such is not the case with Hinduized Meiteis.

While writing a perspective 'analysis of present unrest in Manipur and its solution', Chirom Ranjit, in his Unrest in Manipur, opines that "[i]f the Meitei community retain their original religion or converted into Christianity without conversion into Hinduism or the hill people were converted in to Hinduism, there should 
not have [been] the present gap between the hill and plain people of Manipur" (Ranjit, 2004, p. 32). He has my opinion in that regards, but it is to be argued here that that mistake in the history itself, as stated just above, is not the real issue of the root of the problem but the real issue rather lies in the socio-political environment prevailing at that point of time. To substantiate the point, pertinent question that can be asked is on the existence or otherwise of the hill people in the social and political eyes of those who were converted to Hinduism or the so called elite class, or who may be called the newly high caste groups. The "socio-economic" disequilibrium seemed to have taken place even during that epoch time of event. Was it a policy of 'the least interference' in the social and religious lives of the hill people, and or to leave them only at the mercy of their traditional cultural living without an iota of tendency on the part of the mainstream actors to care for their ascend status? I say this inasmuch as all the resources are controlled by the 'commanding community'.

The people of Manipur often than not tend to draw themselves to the notion that Manipur is rich with varieties of cultures but at the same time forget to find out whether these cultures or any one of them, if they like to be so different, have or has so far practically contributed toward building a modern and common-type of culture needed for their integration and common happiness. In the meantime, the people of Manipur are also drifted away from, as I see, considering the importance to find one, if at all it is there or possible, and ways and means to 'sanskritize', or modernize, or westernize, or even hinduize their 'cultures' for good. It is now highly necessary to critically examine the contributions of these cultures towards building ideal social, religious and political cultures. To do this the people of Manipur, including the political elites, must consider three things, according to Professor Max H. Bazerman of the Harvard Business School in Cambridge, Massachusetts, in the process of "negotiating around cultural differences" (The Hindu, 2014). They are: i) "Consider the individual" as "focussing too much on culture can backfire, especially if the other side is doing the same"; ii) "Broaden your scope" because "[b]y adopting a more inclusive mindset and thinking [....., you'll improve your odds of reaching a successful, lasting agreement"; and iii) "reduce stress" "on intercultural negotiations" as people are "more likely to behave according to cultural stereotype when they face extreme demands on their attention" (The Hindu, 2014).

Another area of 'acquired' culture relates to two political systems that were simultaneously practiced in the hill areas and the valleys. Many Manipur's mainstream scholars and intellectuals contested either the existence of such practices or the blunder committed by the British colonial administrators. The acceptability or otherwise of this line of thought will be assumed only by testing the political behaviour, nature and system of governance adopted by the State today, which I shall discuss later. This compartmentalized political system of the past has shaped their value system and the same has been channelized into and through a kind of cultural identities of contemporary thinking among the tribals. I am not trying to wholly blame the system and the people, who are in control of it, although they are to be blamed to certain extent, rather I am trying to put in pictures where the blunders lie. One thing that should not be forgotten is the fact that the major groups in the society dominate every social and political game inasmuch as we are democratic and this truth is held even where there are wanton or undemocratic practices, which I call 'brute force theory'.

Another area of 'social change', according to Prof. Gangmumei kamei, is in the field of education. While the hill tribals are much more exposed to the western education system in which they were exposed to both literacy and English language knowledge, much more than the plain dwellers, the advantage of western education have much far reaching consequences on the tribals than the Meeteis (Kamei, 2002, pp. 38-41). The better educational level, at least in English knowledge, of the tribal put them into 'sideline' of the mainstream policies and plans.

And on top of these, while the Khongjom War, 1891, did not affect the larger chunks of the tribals, the Kukis' First War of Independence, 1917 - 1919, and the Zalienrongs' movement did not affect the valley areas as such. The impacts of the First and Second world Wars were largely felt in the valley than it was felt by the Hill People. After all these, Manipur attained statehood under the Indian constitution with federal structure in place where the State has prerogatives over the Union Government in terms of power and authority to redress the long-pending grievances of the people of the State.

The Kukis, represented as of now by the Kuki Inpi Manipur (KIM), expressly through the 'traditional principle' found in the KIM's constitution, believe in maintaining peace, respect and harmonious relation with neighbouring communities. To that end, the Kukis have been proposing to the Naga civil societies an agenda for 'settlement' of the issue of the protracted 'NSCN (IM)'s ethnic cleansing perpetrated on the innocent and civilian Kukis in tradition-cultural method. This offer for 'peaceful settlement' of the blunders so committed through cultural approach has not yet been reciprocated from any sections of Manipur's civil societies in general and the state government and the NSCN (IM) (Manipur Nagas) in particular. The cultural ethos of the Kukis, at least in this regard, needs appreciation. The resultant outcome of such approach will bear a lasting impact as a win-win solution. On the other hand, the Nagas' democratic approach, at least at certain level, like, accommodating all smaller tribes to its fold should be appreciated. Even their political and diplomatic ability to 
do so is worth consideration. Their continuous tolerance on various unfolding from 'State' and major communities is something to be emulated of.

In the political arena, it is to be remembered that very few peoples' representatives, read MLAs, from the tribal reserved constituencies speak in the State Legislative Assembly either as opposition or ruling members. They are not alone to be blamed for their inactivity. There is something more than one could assume behind all this. Not only do the Meeteis constitute the majority in the Legislative Assembly, they also command both the opposition and the treasury bench wherein their influencing role is very prominent. In all the political parties in the State also, the 'commanding community' always form the majority. In such situation, the tribals could not be practically blamed for the prevailing political unrests in the State. But to render failure to the State just because of such 'cultural failure' would be a grave mistake on the part of people, especially the commanding community.

On the other hand, the tribals of the State by and large put little efforts or try to understand the social, economic and political realities befalling the majority Meeteis. Sometimes ago, during the 1980s and ' 90 s, the R.K. (Rajkumar) tribe seemed to hold control of at least the major political decision making process among the Meetei society while the Maharaja was at the backstage. The decline of the social and religious authority and power of the King has undermined the social fabrics of the Meeteis. But it is unfortunate that Manipuri civil societies neither could stake claim to their rightful place nor could channelize the social and political authority following such vacuum. This indecisive position of the commanding community defined the state of things in the hands of the few elites who are hand in glove with the adversaries of State development and peace.

\section{Concluding Remarks}

One general perception in vogue among the commanding community in Manipur is that 'had Manipur not merged with the Union of India, Burma, now Myanmar, which is a neighbouring country[,] might have annexed the territory of Manipur or Manipur might have been split into small pieces amongst the different communities settled thereon" and the answer to this doubt or question "is that no such thing would have happened if the people of Manipur were given the opportunity to decide its own fate" (Ranjit, 2004, p. 5). After the princely state has merged with the Union of India, Manipur has been strengthened by the political, economic, and power might of India with its 'federal structure' wherein the fate of the federating unit, say Manipur, is in its own hands. Out of 60 MLAs, 40, the deciding majority, is commanded by the commanding community. The few elite classes from the valley monopolize this commanding position of the Meeteis and the larger chunk of the population of the Meeteis is and has been persistently ignored by them. In this regard Nameirakpam Bijen Meetei opines thus "Instead of expanding the democratic process of decision making by accommodating the voices of diverse communities, this has deepened the cleavages of an already fragmented society" (Meetei, 2014, p. 109). This is how we should pictures the cultural environment of our State. That is to say that the larger Meetei population in general is no exception to marginalization, suppression, and human right violations in the hands of their own ruling elite class.

To unwind the historical blunders committed on the whole population of Manipur is to 'make a clean break with the past by giving it a wholly new and modern identity', as opined by Parekh in the case of India as a whole, by common and concerted effort from both tribals and non-tribals where the influence of contemporary shallow thoughts and ideas coming forth from various angles such as 'look-east policy' and 'globalization' approaches are not given a room to play myopic games, to reign over the hegemonic politics of our own elitecultural groups. This is because blame game will and subsequently newly cherished political autonomies would solve nothing of our socio-political and economic grievances because of limited Sate resources. Nevertheless, as stated elsewhere in this paper, the commanding group has major role to play and unless that could take place, there is nothing wrong with 'Alternative Arrangement' outside of the Government of Manipur (AA) and 'Homeland' because, to recall, 'one's culture is, thus, defined by his/her environment. But one thing is very clear that the 'culture' simply describes his environment but it does not define him or what he is today or what he would ultimately become in future'. It is also now high time for tribals to understand the problems facing the majority Meeteis. This would be the "Political elements for their [our] collective self-definition" inasmuch as 'socio-economic' and of course, 'political disequilibrium' is the root of cultural differences.

Let me conclude by quoting Phukan (2006) who says, the "[...] food habit of the mongoloid people [of North-East India] is secular in nature which has an international character" (Phukan, 2006, p. 199). But narrow and partisan political approaches adopted by different communities in Manipur to either unshackle their historical blunders or to brutalize the existing system for selfish gain are not likely to be a healthy cultural and political trend for all stakeholders alike. Furthering such tendencies is rather likely to unfold more interesting discussion in the near future with lose-lose situation which will be only at the advantage of the ruling elites of all communities at the cost of common people.

$$
\text { (....().... }
$$




\section{References}

[1]. Jha, M. (1999). An Introduction to Anthropological Thought (First published, 1983 ed.). New Delhi: Vikas Publishing House Pvt. Ltd.

[2]. Kamei, G. (2002). Ethnicity and Social change: an Anthology of Change. Imphal: Smt. Pouganglu Gangmei.

[3]. Marino, A. (2014). Narendra Modi: A Political Biography. Noida, Utter Pradesh: HarperCollins Publishers India.

[4]. Meetei, N. B. (2014). Ethnicity, Colonial Legacies, and Postindependence Issues of Identity Politics in North-East India. In 20:1, Nationalism and Ethnic Politics (pp. 99-115). London: Routledge.

[5]. Menon, P. (2014). Pro-unity speakers 'wins' debate. The Hindu , 6 (187), 10

[6]. Negotiating around cultural differences. (2014, August 6). The Hindu, p. 12.

[7]. Parekh, B. (2009). Discourse on National identity. In B. Chkrabarty (Ed.), Communal Identity in Twentieth Century (Third Impression ed., p. 118). New Delhi: Oxford University Press.

[8]. Phukan, G. (2006). Secularism, Ethnicity and Mongolian Culture in North-East India. In B. J. Deb (Ed.), Ethnic Issues, Secularism, and Conflict Resolution in North East India (p. 199). New Delhi: North-east India Council of Social Science Research, Shillong.

[9]. Ranjit, C. (2004). Unrest in Manipur. Imphal: Chirom Ranjit. 